\title{
Distinct Penetrance of Obesity-Associated Susceptibility Alleles in the Hungarian General and Roma Populations
}

\author{
Károly Nagy ${ }^{a}$ Szilvia Fiatal ${ }^{a, b}$ János Sándor ${ }^{a, b} \quad$ Róza Ádány ${ }^{a, b, c}$ \\ a Department of Preventive Medicine, Faculty of Public Health, University of Debrecen, \\ Debrecen, Hungary; ${ }^{b}$ WHO Collaborating Center on Vulnerability and Health, Department \\ of Preventive Medicine, Faculty of Public Health, University of Debrecen, Debrecen, \\ Hungary; ' ${ }^{\mathrm{C}}$ MTA-DE Public Health Research Group of the Hungarian Academy of Sciences, \\ University of Debrecen, Debrecen, Hungary
}

\section{Keywords}

Body mass index $\cdot$ FTO $\cdot$ Gene variants · Obesity $\cdot$ Roma $\cdot$ Gypsy $\cdot$ Genetic risk score

\begin{abstract}
Aims: The aim of our study was to explore differences in genetic predisposition to obesity between the Hungarian general and Roma populations. Methods: A total of 1,152 samples from the Hungarian Roma population and 1,743 samples from the Hungarian general population were genotyped for 20 single nucleotide polymorphisms (SNPs) associated with the risk of obesity. Two types of multilocus genetic risk scores were constructed to estimate the combined effect of selected SNPs. Results: Risk allele frequencies differed significantly between the two populations for 11 SNPs, with no enrichment in any of the two study groups. Variants (rs1558902, rs1121980, rs9939609, and rs9941349) in the fat mass and obesity-associated (FTO) gene exhibited strong but ethnicity-independent association with obesity. Genetic risk scores showed stronger associations with obesity in the Roma population compared with the Hungarian general population; however, without significant gene-population interaction. Conclusion: Differences in obesity prevalence between the Hungarian general and Hungarian Roma populations could not be explained by their distinct genetic susceptibility, rather by ethnicity-related environmental and behavioral factors. Nonetheless, particular gene-environment interactions might contribute to the distinct penetrance of the obesity-associated genetic factors in populations of different ethnic backgrounds.
\end{abstract}




\section{Introduction}

Obesity, one of the strongest cardiovascular risk factors, is a serious public health challenge for the 21st century. Recently, a health examination survey revealed $26.2 \%$ and $30.4 \%$ prevalence of obesity in the Hungarian adult male and female populations, respectively [1]. These values ranked Hungary as the number one 'most obese member state' in the European Union [2], which clearly indicates the need of collecting more information and conducting studies about the potential factors influencing obesity on the Hungarian population.

The population of Hungary is reasonably diverse with many ethnic minorities, among them the Roma (Gypsy) who account for approximately 7\% of the population [3]. Hungarians originate from the eastern side of the Ural Mountains, whereas the Roma people are from the Indian subcontinent. Genetic ancestry studies have provided sufficient evidence that the Roma's ancestors migrated to Europe about 850 years ago, with a severe founder event and a very little genetic admixture occurring with populations encountered on the way. After settled in the Balkans, this initial population fragmented and dispersed throughout Europe resulting in the mixture of their genomes with those of various European ethnic groups, including Hungarians. Despite the fact that today's Hungarian Gypsies have genetic variants typical of India and Europe, the two populations fundamentally differ from each other in their genetic architectures $[4,5]$. Recent genetic epidemiological studies also indicated significant genetic differences between the Hungarian general (HG) and Hungarian Roma (HR) populations [6-9].

Generally, the Roma minority is considered to possess unfavorable health and live in a less healthy environment (colonies) than the majority of the population, not only in Hungary but also in other European countries [10]. The low educational status as well as high unemployment and poverty rates may further contribute to ill health among the Roma [11]. Because of the generally high prevalence of adverse risk factors such as obesity, metabolic syndrome, hypertension, smoking and alcohol consumption, this population is at an increased risk of diabetes, cardiovascular diseases and, consequently, early mortality [12-14]. Studies investigating anthropometric features in Roma populations in Slovakia, Spain, and Serbia have suggested that the prevalence of obesity and BMI are higher among the Roma than in the general population [15-17].

Environmental factors play a crucial role in the development of obesity; however, there is no doubt that it is also influenced by genetics [18]. In the past few years, genome-wide association studies (GWAS) identified dozens of polymorphisms in genes or gene regulatory regions involved in energy homeostasis, appetite regulation as well as lipid and carbohydrate metabolism that have cumulative effects on body weight [19]. However, most of these studies were performed in populations of European descent. The results of genetic replication studies investigating the relationship between SNPs identified by GWAS and obesity-related traits were not always consistent. The reasons could be that these studies were conducted in populations with different environmental characteristics and/or were performed on samples of relatively small size. Furthermore, there is a considerable genetic heterogeneity across populations in terms of allele frequency, linkage disequilibrium (LD), and haplotype structure that can arise as a result of multiple factors such as genetic drift, mutations, and natural selection. If a true functional SNP is in strong LD with the lead SNP in the population in which the GWAS was performed, but not in a different population, then the lead SNP will not be associated with the phenotype in this second population. Thus, interethnic differences in LD block patterns limit the generalizability of GWAS association signals across populations [20]. Consequently, differences within and among human communities in terms of susceptibility to obesity could be explained by the different genetic background of a population and/or its interaction with various environmental exposures [21]. Moreover, it has not been clarified how much these 
SNPs contribute to obesity risk and related quantitative factors if combined and whether they can be considered as possible predictors of obesity, which might have implications for early prevention and intervention.

The present study was designed to explore differences in genetic predisposition to obesity between the HG and HR populations by investigating the distribution of 20 recently identified obesity susceptibility loci as well as their association, individually and in combination, with the prevalence of obesity.

\section{Subjects and Methods}

\section{Study Sample of the Hungarian General Population}

In 2006, a cross-sectional study was conducted based on the General Practitioners' Morbidity Sentinel Stations Program to define the prevalence of metabolic syndrome in the Hungarian population [22]. The source population of the study included all individuals aged 20-69 years who were registered by the 59 participating general practitioners (GPs) of eight Hungarian counties. The study population was randomly selected proportional to the size of the practices to represent the Hungarian adult population based on geographic, age, and sex distributions. GPs performed physical examinations (weight, height, blood pressure measurements) and collected blood samples for laboratory investigations and DNA isolation. Information on the sociodemographic status, family history, and lifestyle were also collected using self-administered questionnaires. In the framework of this study, 1,783 DNA samples were acquired.

\section{Study Sample of the Hungarian Roma Population}

The study population was enrolled from counties in Northeast Hungary, the area where the Roma are most prevalent and the majority of segregated Roma colonies are located. The participants were interviewed by Roma field workers in the framework of two surveys conducted recently [23, 24]. The ethnicity of the participants was assessed by self-declaration. 92 segregated colonies with more than 100 inhabitants were considered in the surveys, of which 65 were randomly selected using the GPs' validated household lists. Afterwards, 25 households in each colony were randomly chosen, and one person from each household was invited to the GPs. As a part of the health examination survey, physical examinations (weight, height, blood pressure measurements) were performed, and whole blood samples were taken for routine laboratory tests and DNA extraction. Data on sociodemographic factors, lifestyle, and self-assessed health status were obtained using interviewer-assisted questionnaires. A total of 1,170 DNA samples from 20- to 69-year-old Roma individuals were used for genotyping.

\section{Genotyping}

Genomic DNA was extracted from EDTA-coagulated whole blood samples using the MagNa Pure LC DNA Isolation Kit - Large Volume (Roche Diagnostics, Mannheim, Germany) according to the manufacturer's instructions. Genotyping was performed in the Mutation Analysis Core Facility (MAF) of the Karolinska University Hospital (Stockholm, Sweden) using the Sequenom MassARRAY platform (Sequenom Inc., San Diego, CA, USA) with iPLEX Gold chemistry [25]. Validation, concordance analysis and quality control were conducted by the MAF according to their protocols, resulting in a successful genotyping outcome for 2,895 (1,743 Hungarian and 1,152 Roma) DNA samples.

\section{SNP Selection and Computation of Genetic Risk Score}

A systematic literature review was undertaken in the PubMed database with an emphasis on GWAS to identify SNPs that were found to play a significant role in the development of obesity. Given that most GWAS have described common obesity-associated gene loci in European-descent populations, multi-ancestral meta-analyses were also examined to discover gene polymorphisms showing association with obesity in populations with different ethnic background. SNP selection was based on HapMap data for a European ancestry population sample (CEU) with a minor-allele frequency > 5\% (www.hapmap.org) and previously published results showing significant associations between these polymorphisms and obesity-related traits. The top 20 SNPs, identified by the magnitude of the described association (odds ratio or beta value), were selected for further genotyping (table 1). 
Nagy et al.: Distinct Penetrance of Obesity-Associated Susceptibility Alleles in the Hungarian General and Roma Populations

Table 1. Obesity predisposing SNPs selected for the study

\begin{tabular}{|c|c|c|c|c|c|}
\hline \multirow[t]{2}{*}{ SNP } & \multicolumn{2}{|l|}{ Gene } & \multicolumn{2}{|c|}{ Described association } & \multirow[t]{2}{*}{ Reference } \\
\hline & name & abbreviation & $\begin{array}{l}\text { odds ratio of } \\
\text { obesity }\end{array}$ & $\begin{array}{l}\text { mean difference in } \\
\text { BMI }(\beta)\end{array}$ & \\
\hline rs1137101 & leptin receptor & $L E P R$ & 1.13 & - & Paracchini et al. [26] \\
\hline rs2815752 & neuronal growth regulator & NEGR1 & - & 0.13 & Speliotes et al. [27] \\
\hline $\begin{array}{l}\text { rs2867125 } \\
\text { rs6548238 }\end{array}$ & transmembrane protein 18 & TMEM18 & $\begin{array}{l}- \\
-\end{array}$ & $\begin{array}{l}0.31 \\
0.26\end{array}$ & $\begin{array}{l}\text { Speliotes et al. [27] } \\
\text { Willer et al. [28] }\end{array}$ \\
\hline rs1801282 & $\begin{array}{l}\text { peroxisome proliferator- } \\
\text { activated receptor gamma }\end{array}$ & $P P A R G$ & - & 0.06 & Galbete et al. [29] \\
\hline $\begin{array}{l}\text { rs2241766 } \\
\text { rs1501299 }\end{array}$ & $\begin{array}{l}\text { adiponectin, } \mathrm{C} 1 \mathrm{Q} \text { and } \\
\text { collagen domain containing }\end{array}$ & $A D I P O Q$ & $\begin{array}{l}1.39 \\
0.89\end{array}$ & - & $\begin{array}{l}\text { Wu et al. [30] } \\
\text { Lu et al. [31] }\end{array}$ \\
\hline rs1093839 & $\begin{array}{l}\text { 7glucosamine-6-phosphate } \\
\text { deaminase } 2\end{array}$ & GNPDA2 & - & 0.18 & Speliotes et al. [27] \\
\hline $\begin{array}{l}\text { rs16139 } \\
\text { rs925946 } \\
\text { rs6265 }\end{array}$ & $\begin{array}{l}\text { neuropeptide } Y \\
\text { brain-derived neurotrophic } \\
\text { factor }\end{array}$ & $\begin{array}{l}N P Y \\
B D N F\end{array}$ & $\begin{array}{l}- \\
1.11 \\
1.12\end{array}$ & $\begin{array}{l}0.58 \\
- \\
-\end{array}$ & $\begin{array}{l}\text { Yeung et al. [32] } \\
\text { Thorleifsson et al. [33] } \\
\text { Thorleifsson et al. [33] }\end{array}$ \\
\hline $\begin{array}{l}\text { rs660339 } \\
\text { rs659366 }\end{array}$ & $\begin{array}{l}\text { uncoupling protein } 2 \\
\text { (mitochondrial, proton } \\
\text { carrier) }\end{array}$ & UCP2 & - & $\begin{array}{l}0.39 \\
-\end{array}$ & $\begin{array}{l}\text { Brondani et al. [34] } \\
\text { Brondani et al. [34] }\end{array}$ \\
\hline $\begin{array}{l}\text { rs6499640 } \\
\text { rs1558902 } \\
\text { rs1121980 } \\
\text { rs9939609 } \\
\text { rs9941349 }\end{array}$ & $\begin{array}{l}\text { fat mass and obesity- } \\
\text { associated protein }\end{array}$ & FTO & $\begin{array}{l}1.16 \\
- \\
- \\
- \\
-\end{array}$ & $\begin{array}{l}- \\
0.39 \\
0.31 \\
0.33 \\
0.56\end{array}$ & $\begin{array}{l}\text { Thorleifsson et al. [33] } \\
\text { Speliotes et al. [27] } \\
\text { Vimaleswaran et al. [35] } \\
\text { Willer et al. [28] } \\
\text { Cronin et al. [36] }\end{array}$ \\
\hline $\begin{array}{l}\text { rs17782313 } \\
\text { rs1297013 }\end{array}$ & $\begin{array}{l}3 \text { melanocortin } 4 \text { receptor } \\
4\end{array}$ & $M C 4 R$ & $-\overline{1.12}$ & $\begin{array}{l}0.2 \\
-\end{array}$ & $\begin{array}{l}\text { Willer et al. [28] } \\
\text { Thorleifsson et al. [30] }\end{array}$ \\
\hline
\end{tabular}

Two types of multilocus genetic risk score (GRS) were constructed for each individual in the study populations. GRS1 incorporated all independent SNPs, while GRS2 included only SNPs associated with obesity with a $\mathrm{p}<0.05$ in the present study. Only one representative SNP was selected from a LD block if there were absolute LDs with $\mathrm{r}^{2} \geq 0.2$. GRS was defined by a simple count method (i.e., by summation of the number of risk alleles) assuming additive genetic model in which each risk allele contributes equally to the risk for obesity, and summed over all the SNPs in the set.

\section{Statistical Analysis}

Data were analyzed using PLINK v1.07 (http://pngu.mgh.harvard.edu/purcell/plink) [37], Stata v12.0 (StataCorp LP, College Station, TX, USA) and CaTs [38] software. Departure from Hardy-Weinberg equilibrium (HWE) as well as differences in obesity prevalence and the allele frequencies of individual SNPs were calculated with Pearson's chi-square test. Distributions of risk allele frequencies and genetic risk scores in the two study populations were compared by binomial distribution and Kolmogorov-Smirnov tests, respectively. To estimate the risk of obesity $\left(18.5 \leq \mathrm{BMI}<25 \mathrm{~kg} / \mathrm{m}^{2} \mathrm{vs}\right.$. BMI $\left.\geq 30 \mathrm{~kg} / \mathrm{m}^{2}\right)$ for each SNP, we calculated the odds ratio (OR) and 95\% confidence intervals (95\% CI) using multivariate logistic regression. To ensure the highest statistical power, data of the two study groups were analyzed jointly. In the regression analyses, the additive model was used and adjusted for covariates including age, gender and ethnicity. The possible interethnic differences in the association patterns were assessed by introducing a multiplicative interaction 

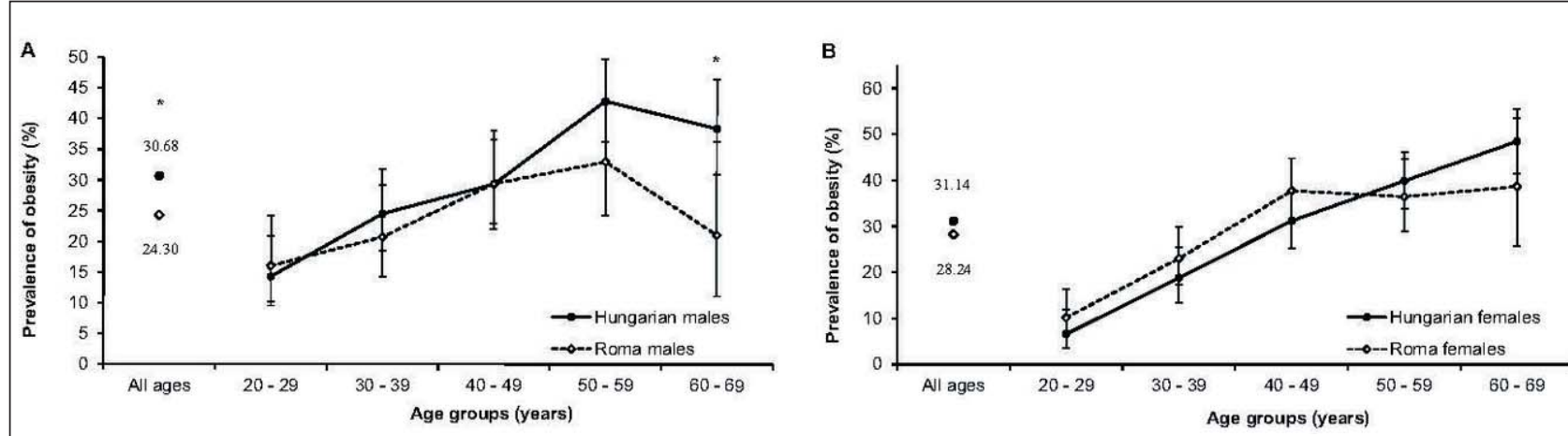

Fig. 1. Age-specific prevalence ( $\% ; 95 \% \mathrm{CI})$ of obesity in the Hungarian general and Roma populations among males $(\mathbf{A})$ and females (B). Statistically significant differences are indicated by asterisks $\left({ }^{*} \mathrm{p}<0.05\right)$.

term in the model assuming additive allelic effect and dichotomus ethnicity. The threshold for statistical significance was 0.05 . The power to detect association was calculated using the minor allele frequency of each SNP in our case-control samples and the effect size calculated in the allelic association analysis.

In a further analysis, we evaluated the association of genetic risk scores with obesity risk $(18.5 \leq \mathrm{BMI}<$ $25 \mathrm{~kg} / \mathrm{m}^{2}$ vs. BMI $\geq 30 \mathrm{~kg} / \mathrm{m}^{2}$ ) using multivariate logistic regression models. Interactions between genetic effects and ethnicity were analyzed by introducing the corresponding interaction term into the models as well.

\section{Results}

Demographic Characteristics and Distribution of Obesity Prevalence in the Study

Populations

Differences in demographic characteristics, as well as in the distribution of obesity prevalence were observed between the HG and HR population samples (table 2, fig. 1). The female proportion was higher in the HR (59.6\%) than in the HG (53.1\%) population, although women were the majority in both study samples in all age groups, except the 20- to 29-year-old HG group. The age distribution of the HR sample was slightly shifted towards the younger age groups compared to the HG sample. The average ages in the HG and HR populations were 46 and 41.4 years, respectively.

The prevalence of obesity in both men and women were higher in the HG than in the HR population with significant difference only between HG and HR males. Obesity was less frequently observed among men than women in both study groups. The age- and sex-specific prevalence of obesity followed a similar pattern in younger age groups in both samples; however, in age groups older than 40-49 years, the proportion of HR people with obesity, especially of males, was strongly reduced.

\section{Frequency and Impact of SNPs in the Study Populations}

All SNPs were in Hardy-Weinberg equilibrium in both study groups. Eleven obesitypredisposing polymorphisms showed significant difference in the risk allele frequencies between the two study groups (table 3). Six of them had significantly higher risk allele frequency in the HR population. Nonetheless, when comparing the risk allele distribution of the entire SNP panel between the two study populations, none of them were significantly enriched by obesity-associated genetic markers. 
Nagy et al.: Distinct Penetrance of Obesity-Associated Susceptibility Alleles in the Hungarian General and Roma Populations

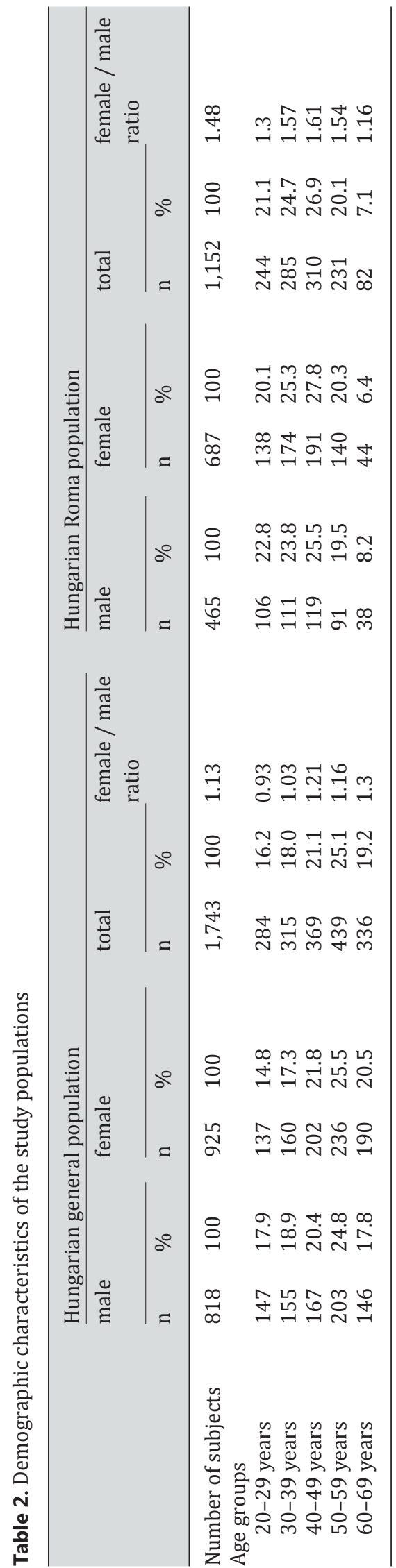


Table 3. Allele frequencies of individual SNPs in the Hungarian general and Roma populations
Nagy et al.: Distinct Penetrance of Obesity-Associated Susceptibility Alleles in the Hungarian General and Roma Populations

\begin{tabular}{|c|c|c|c|c|}
\hline \multirow[t]{2}{*}{ Gene / SNP } & \multirow[t]{2}{*}{ Risk allele } & \multicolumn{3}{|c|}{ Risk allele frequency } \\
\hline & & $\mathrm{HG}$ & HR & $\mathrm{P}_{\text {for difference }}$ \\
\hline \multicolumn{5}{|l|}{$L E P R$} \\
\hline rs1137101 & G & 0.46 & 0.44 & 0.267 \\
\hline \multicolumn{5}{|l|}{ NEGR1 } \\
\hline \multirow{2}{*}{\multicolumn{5}{|c|}{ TMEM18 }} \\
\hline & & & & \\
\hline rs2867125 & $\mathrm{C}$ & 0.81 & 0.86 & $<0.001$ \\
\hline rs6548238 & $\mathrm{C}$ & 0.81 & 0.89 & $<0.001$ \\
\hline \multicolumn{5}{|l|}{$P P A R G$} \\
\hline rs1801282 & $\mathrm{C}$ & 0.13 & 0.05 & $<0.001$ \\
\hline \multicolumn{5}{|l|}{$A D I P O Q$} \\
\hline rs2241766 & G & 0.11 & 0.11 & 0.916 \\
\hline rs1501299 & $\mathrm{T}$ & 0.29 & 0.28 & 0.32 \\
\hline \multicolumn{5}{|l|}{ GNPDA2 } \\
\hline rs10938397 & G & 0.46 & 0.41 & 0.001 \\
\hline \multicolumn{5}{|l|}{$N P Y$} \\
\hline rs16139 & $\mathrm{C}$ & 0.04 & 0.02 & $<0.001$ \\
\hline \multicolumn{5}{|l|}{$B D N F$} \\
\hline rs925946 & $\mathrm{T}$ & 0.26 & 0.37 & $<0.001$ \\
\hline rs6265 & $\mathrm{C}$ & 0.8 & 0.89 & $<0.001$ \\
\hline \multicolumn{5}{|l|}{ UCP2 } \\
\hline rs660339 & G & 0.59 & 0.63 & 0.001 \\
\hline rs659366 & $\mathrm{C}$ & 0.63 & 0.65 & 0.146 \\
\hline \multicolumn{5}{|l|}{ FTO } \\
\hline rs6499640 & A & 0.59 & 0.51 & $<0.001$ \\
\hline rs1558902 & A & 0.45 & 0.43 & 0.037 \\
\hline rs1121980 & A & 0.47 & 0.46 & 0.571 \\
\hline rs9939609 & A & 0.44 & 0.43 & 0.373 \\
\hline rs9941349 & $\mathrm{T}$ & 0.45 & 0.43 & 0.246 \\
\hline \multicolumn{5}{|l|}{$M C 4 R$} \\
\hline rs17782313 & $\mathrm{C}$ & 0.22 & 0.22 & 0.629 \\
\hline rs12970134 & A & 0.24 & 0.22 & 0.063 \\
\hline
\end{tabular}

$\mathrm{HG}=$ Hungarian general population; $\mathrm{HR}=$ Hungarian Roma population.

The FTO gene variants, namely rs1558902, rs1121980, rs9939609 and rs9941349, showed a strong association with obesity in the joint analysis, as indicated by the odds ratios of 1.34 (95\% CI 1.17-1.54; p < 0.001), 1.35 (95\% CI 1.18-1.56; p < 0.001), 1.35 (95\% CI 1.17$1.55 ; \mathrm{p}<0.001)$ and 1.41 (95\% CI 1.22-1.62; $<<0.001)$. Further association signals could be replicated for SNPs in the GNPDA2 (rs10938397), NPY (rs16139), FTO (rs6499640), and MC4R (rs17782313 and rs12970134) genes. The sample size of the joint analysis permitted relatively high power (86-100\%) for these SNPs to detect association when allowing a falsepositive rate of 0.05 . However, the sample size showed rather low power for the other SNPs (5-64\%) suggesting that they have almost no or a rather weak contribution to the development of obesity in the study populations. In addition, significant interaction between genetic variants and ethnicity could be observed only for rs1801282 in the PPARG gene, indicating virtually the absence of ethnicity-related genetic predisposition to obesity in our study sample (table 4). 
Table 4. Associations of individual SNPs with obesity in the study populations (joint analysis) and interactions between individual SNPs and ethnicity*

\begin{tabular}{|c|c|c|c|c|c|c|c|c|}
\hline \multirow[t]{2}{*}{ Gene / SNP } & \multirow{2}{*}{$\begin{array}{l}\text { Risk } \\
\text { allele }\end{array}$} & \multirow[t]{2}{*}{$\mathrm{OR}^{\mathrm{a}}(95 \% \mathrm{CI})$} & \multirow[t]{2}{*}{$\mathrm{p}$} & \multirow{2}{*}{$\begin{array}{l}\text { Power }(\%)^{b} \\
(p=0.05)\end{array}$} & \multicolumn{2}{|c|}{ Expected sample size ${ }^{c}$} & \multicolumn{2}{|c|}{ Interaction analysis ${ }^{\mathrm{d}}$} \\
\hline & & & & & case & control & $\mathrm{OR}^{\mathrm{a}}(95 \% \mathrm{CI})$ & $\mathrm{p}$ \\
\hline $\begin{array}{l}L E P R \\
\text { rs1137101 }\end{array}$ & $\mathrm{G}$ & $1.01(0.87-1.16)$ & 0.941 & 5 & $>100,000$ & $>100,000$ & $0.88(0.66-1.75)$ & 0.391 \\
\hline $\begin{array}{l}\text { NEGR1 } \\
\text { rs2815752 }\end{array}$ & $\mathrm{A}$ & $1.13(0.97-1.31)$ & 0.119 & 64 & 1,313 & 1,313 & $0.95(0.69-1.31)$ & 0.772 \\
\hline $\begin{array}{l}\text { TМЕМ18 } \\
\text { rs2867125 } \\
\text { rs6548238 }\end{array}$ & $\begin{array}{l}\mathrm{C} \\
\mathrm{C}\end{array}$ & $\begin{array}{l}1.08(0.89-1.30) \\
1.15(0.95-1.39)\end{array}$ & $\begin{array}{l}0.416 \\
0.159\end{array}$ & $\begin{array}{l}23 \\
58\end{array}$ & $\begin{array}{l}4,826 \\
1,447\end{array}$ & $\begin{array}{l}4,826 \\
1,447\end{array}$ & $\begin{array}{l}1.09(0.74-1.63) \\
1.33(0.87-2.04)\end{array}$ & $\begin{array}{l}0.641 \\
0.188\end{array}$ \\
\hline $\begin{array}{l}\text { PPARG } \\
\text { rs1801282 }\end{array}$ & $\mathrm{C}$ & 1.08 (0.85-1.37) & 0.519 & 16 & 7,595 & 7,595 & $0.57(0.33-0.98)$ & $<0.05$ \\
\hline $\begin{array}{l}A D I P O Q \\
\text { rs2241766 } \\
\text { rs1501299 }\end{array}$ & $\begin{array}{l}\mathrm{G} \\
\mathrm{T}\end{array}$ & $\begin{array}{l}1.08(0.86-1.34) \\
1.13(0.97-1.32)\end{array}$ & $\begin{array}{l}0.639 \\
0.129\end{array}$ & $\begin{array}{l}17 \\
63\end{array}$ & $\begin{array}{l}6,905 \\
1,370\end{array}$ & $\begin{array}{l}6,905 \\
1,370\end{array}$ & $\begin{array}{l}1.11(0.71-1.74) \\
0.91(0.66-1.24)\end{array}$ & $\begin{array}{l}0.635 \\
0.556\end{array}$ \\
\hline $\begin{array}{l}\text { GNPDA2 } \\
\text { rs10938397 }\end{array}$ & $\mathrm{G}$ & 1.17 (1.01-1.34) & $<0.05$ & 87 & 749 & 749 & $1.21(0.91-1.61)$ & 0.19 \\
\hline $\begin{array}{l}N P Y \\
\text { rs16139 }\end{array}$ & $\mathrm{C}$ & $0.56(0.38-0.81)$ & $<0.01$ & 100 & 239 & 239 & $0.88(0.37-2.11)$ & 0.778 \\
\hline $\begin{array}{l}B D N F \\
\text { rs925946 } \\
\text { rs6265 }\end{array}$ & $\begin{array}{l}\mathrm{T} \\
\mathrm{C}\end{array}$ & $\begin{array}{l}1.13(0.97-1.32) \\
1.16(0.95-1.39)\end{array}$ & $\begin{array}{l}0.114 \\
0.139\end{array}$ & $\begin{array}{l}64 \\
64\end{array}$ & $\begin{array}{l}1,332 \\
1,311\end{array}$ & $\begin{array}{l}1,332 \\
1,311\end{array}$ & $\begin{array}{l}1.03(0.76-1.39) \\
0.85(0.56-1.28)\end{array}$ & $\begin{array}{l}0.859 \\
0.434\end{array}$ \\
\hline $\begin{array}{l}\text { UCP2 } \\
\text { rs660339 } \\
\text { rs659366 }\end{array}$ & $\begin{array}{l}\mathrm{G} \\
\mathrm{C}\end{array}$ & $\begin{array}{l}1.09(0.95-1.26) \\
1.09(0.94-1.26)\end{array}$ & $\begin{array}{l}0.235 \\
0.245\end{array}$ & $\begin{array}{l}41 \\
40\end{array}$ & $\begin{array}{l}2,398 \\
2,454\end{array}$ & $\begin{array}{l}2,398 \\
2,454\end{array}$ & $\begin{array}{l}1.21(0.9-1.61) \\
1.12(0.84-1.49)\end{array}$ & $\begin{array}{l}0.206 \\
0.054\end{array}$ \\
\hline $\begin{array}{l}\text { FTO } \\
\text { rs6499640 } \\
\text { rs1558902 } \\
\text { rs1121980 } \\
\text { rs9939609 } \\
\text { rs9941349 }\end{array}$ & $\begin{array}{l}\mathrm{A} \\
\mathrm{A} \\
\mathrm{A} \\
\mathrm{A} \\
\mathrm{T}\end{array}$ & $\begin{array}{l}1.12(0.98-1.29) \\
1.34(1.17-1.54) \\
1.35(1.18-1.56) \\
1.35(1.17-1.55) \\
1.41(1.22-1.62)\end{array}$ & $\begin{array}{l}0.103 \\
<0.001 \\
<0.001 \\
<0.001 \\
<0.001\end{array}$ & $\begin{array}{l}62 \\
100 \\
100 \\
100 \\
100\end{array}$ & $\begin{array}{l}1,389 \\
241 \\
232 \\
229 \\
181\end{array}$ & $\begin{array}{l}1,389 \\
241 \\
232 \\
229 \\
181\end{array}$ & $\begin{array}{l}1.07(0.81-1.42) \\
1.21(0.91-1.61) \\
1.21(0.91-1.61) \\
1.19(0.89-1.58) \\
1.24(0.93-1.65)\end{array}$ & $\begin{array}{l}0.631 \\
0.184 \\
0.184 \\
0.224 \\
0.142\end{array}$ \\
\hline $\begin{array}{l}M C 4 R \\
\text { rs17782313 } \\
\text { rs12970134 }\end{array}$ & $\begin{array}{l}\mathrm{C} \\
\mathrm{A}\end{array}$ & $\begin{array}{l}1.19(1.01-1.42) \\
1.19(1.04-1.41)\end{array}$ & $\begin{array}{l}<0.05 \\
<0.05\end{array}$ & $\begin{array}{l}86 \\
87\end{array}$ & $\begin{array}{l}782 \\
754\end{array}$ & $\begin{array}{l}782 \\
754\end{array}$ & $\begin{array}{l}0.9(0.64-1.23) \\
0.87(0.62-1.22)\end{array}$ & $\begin{array}{l}0.563 \\
0.431\end{array}$ \\
\hline $\begin{array}{r}{ }^{\mathrm{a}} \text { Increase } \\
\text { tional risk all } \\
{ }^{\mathrm{b}} \mathrm{CaTs} \text { soft } \\
\text { assumed 28\% } \\
{ }^{\mathrm{c}} \text { Minimum } \\
{ }^{\mathrm{d}} \text { Based on } \\
{ }^{*} \text { Regressi }\end{array}$ & $\begin{array}{l}\text { he odd } \\
\text { re [38] } \\
\text { cordin } \\
\text { mple si } \\
\text { del ass } \\
\text { nodels }\end{array}$ & $\begin{array}{l}\text { f being obese (BM } \\
\text { ere used for the p } \\
\text { the literature [1] } \\
\text { that permits to de } \\
\text { hing additive alleli } \\
\text { re adjusted for ag }\end{array}$ & $\begin{array}{l}30 \mathrm{~kg} / \mathrm{m} \\
\text { er calcul } \\
\text { t signific } \\
\text { fect and } \\
\text { ender ar }\end{array}$ & $\begin{array}{l}\mathrm{n}^{2} \text { ) versus beir } \\
\text { lation under a } \\
\text { cant ( } \mathrm{p}<0.05) \\
\text { d dichotomus } \\
\text { and ethnicity. }\end{array}$ & $\begin{array}{l}\text { Ing normal v } \\
\text { additive gen } \\
\text { association } \\
\text { ethnicity in }\end{array}$ & $\begin{array}{l}\text { weight (18.5 } \\
\text { hetic model a } \\
\text { with the po } \\
\text { a multiplica }\end{array}$ & $\begin{array}{l}\mathrm{MI}<25 \mathrm{~kg} / \mathrm{m}^{2} \text { ) for } \\
\text { the prevalence of o } \\
\text { of } 80 \% \text {. } \\
\text { interaction term. }\end{array}$ & each a \\
\hline
\end{tabular}




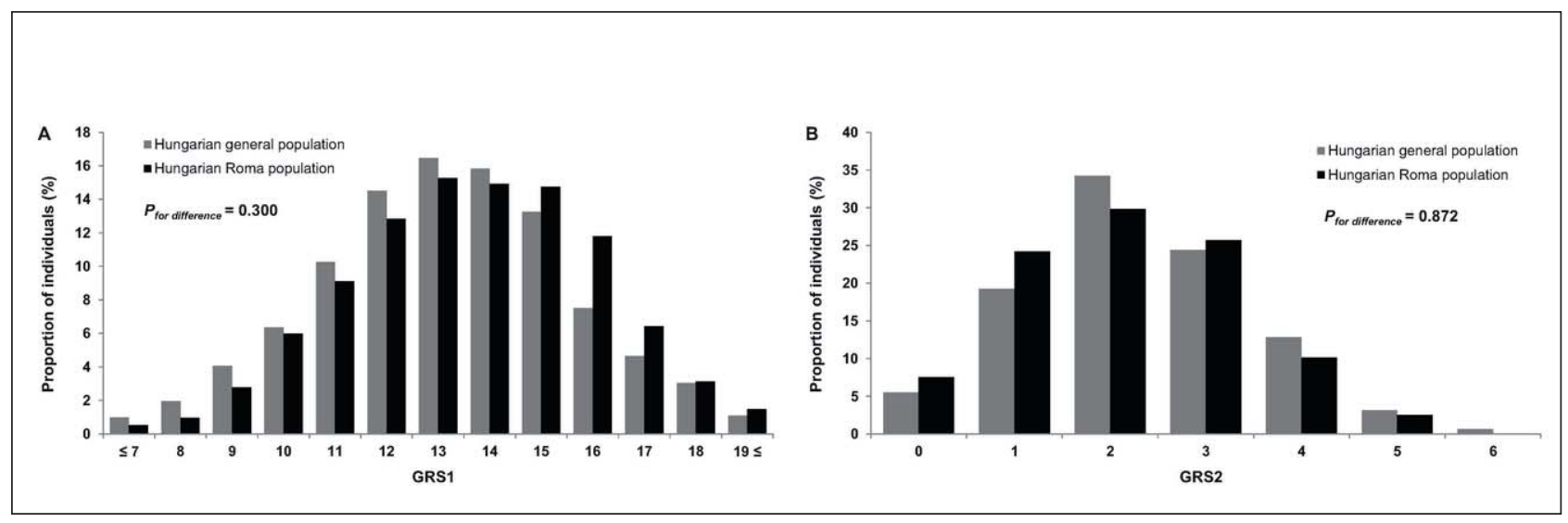

Fig. 2. Distribution of the GRS1 combining 14 SNPs (A) and GRS2 combining 4 SNPs (B) in the Hungarian general (grey) and Hungarian Roma (black) populations.

\section{Obesity according to Genetic Risk Score}

A set of 14 independent variants was used to calculate GRS1, while GRS2 was constructed by using four independent SNPs that were associated significantly with obesity in the target samples. SNPs were considered as independent if the LD between them had $\mathrm{r}^{2}<0.2$. Individual GRS1 and GRS2 ranged from 5 to 20 and from 0 to 6 among our study subjects, respectively, with higher scores indicating a higher genetic predisposition to obesity. Individuals with less than 7 or more than 19 GRS1 were aggregated because of the small number of observations in those groups. GRSs followed normal distributions which were not significantly different (GRS1 $\mathrm{p}=0.3$; GRS2 $\mathrm{p}=0.872$ ) between the two study groups (fig. 2).

Significant positive linear relationships were observed between both GRSs and the studied phenotype (fig. 3). GRS2 displayed higher predictive value than GRS1, as indicated by higher odds ratios. Each additional GRS1 and GRS2 unit, corresponding to one risk allele, was significantly associated with a $3 \%$ (95\% CI 1.01-1.05; $\mathrm{p}=0.003)$ and $19 \%$ (95\% CI 1.1-1.28; $\mathrm{p}<0.001$ ) increase in risk of obesity, respectively, if the two populations were analyzed together. Although significant interaction between the genetic risk and ethnicity could not be observed, both GRSs exhibited different association patterns between the HG and HR populations (table 5). Stratification by ethnicity revealed that a one-unit increment in GRS1 and GRS2 in the HR individuals was significantly associated with a $12 \%$ (95\% CI 1.05-1.18; $p=0.001$ ) and 27\% (95\% CI 1.12-1.45; $p<0.001$ ) higher risk of obesity, respectively. The correlation between GRSs and obesity was less pronounced in the HG study sample.

\section{Discussion}

There is general agreement that in a genetically isolated population with low environmental variability, such as the Roma, the founder effect and genetic drift can cause an increase in the frequency of particular alleles [39]. In this study, we reported significantly higher risk allele frequencies for SNPs in NEGR1 (rs2815752), TMEM18 (rs2867125 and rs6548238), $B D N F$ (rs925946 and rs6265), and UCP (rs660339) genes but significantly lower risk allele frequencies for variants in GNPDA2 (rs10938397), NPY (rs16139), PPARG (rs1801282), and FTO (rs6499640 and rs1558902) genes in HR compared with the HG population. By comparing 


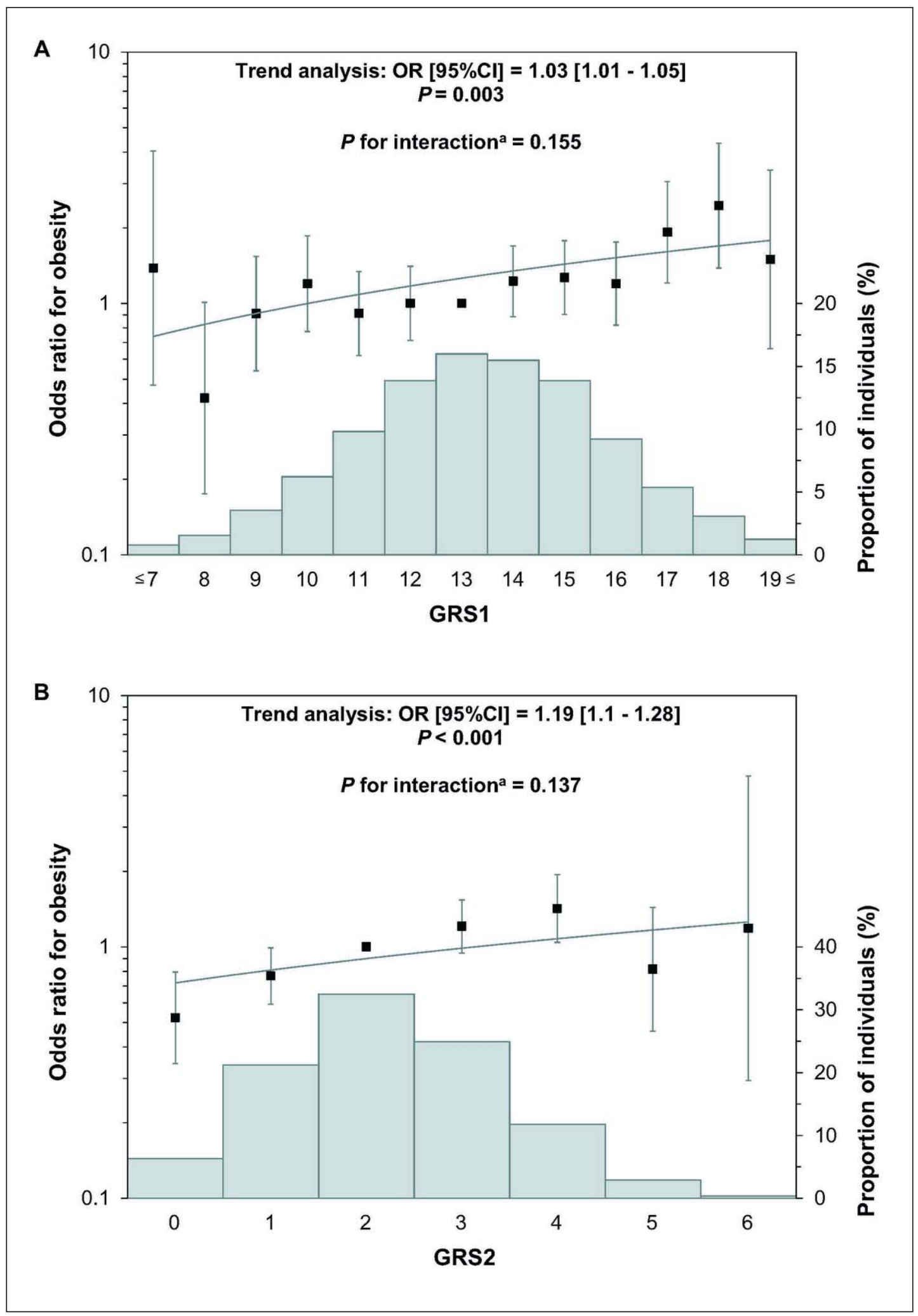

Fig. 3. Association of GRS1 combining 14 SNPs (A) and GRS2 combining 4 SNPs (B) with obesity in the study populations (joint analyses). Histograms (Y axis on right, grey bars) represent the percentage of individuals in each risk score category. Odds ratios and mean BMI (Y axis on left) are plotted. Error bars represent 95\% confidence intervals. 
Table 5. Associations of the GRS1 combining 14 SNPs and GRS2 combining 4 SNPs with risk of obesity in the Hungarian general and Hungarian Roma populations

\begin{tabular}{|c|c|c|c|c|}
\hline & \multicolumn{2}{|c|}{ Hungarian general population } & \multicolumn{2}{|c|}{ Hungarian Roma population } \\
\hline & $\mathrm{OR}^{\mathrm{a}}(95 \% \mathrm{CI})$ & $P_{\text {for trend }}{ }^{b}$ & $\mathrm{OR}^{\mathrm{a}}(95 \% \mathrm{CI})$ & $\mathrm{P}_{\text {for trend }} \mathrm{b}^{\mathrm{b}}$ \\
\hline GRS1 & $1.11(1.04-1.17)$ & $<0.001$ & $1.12(1.05-1.18)$ & 0.001 \\
\hline GRS2 & $1.14(1.02-1.27)$ & 0.018 & $1.27(1.12-1.45)$ & $<0.001$ \\
\hline
\end{tabular}

${ }^{a}$ Increase in the odds of being obese (BMI $\left.\geq 30 \mathrm{~kg} / \mathrm{m}^{2}\right)$ versus being normal weight $(18.5 \leq \mathrm{BMI}<$ $25 \mathrm{~kg} / \mathrm{m}^{2}$ ) for each additional genetic risk score.

${ }^{\mathrm{b}} P_{\text {for trend }}$ values were adjusted for age and gender.

the distribution of investigated risk allele variants, increased genetic predisposition to obesity in the Roma could not be confirmed in this study.

The SNPs with the most robust effect on obesity in our target populations were found in the intronic region of the FTO gene, which is mainly involved in the regulation of energy homeostasis and body composition. However, despite intensive research its exact pathomechanism is still not completely understood [40]. The impacts of FTO gene polymorphisms found in this study were consistent with previous reports not only in European-descent populations $[28,35,36]$ but also in the Slovakian Roma [41], indicating that the effect of these susceptibility loci for obesity persists across populations with various ancestral origins. Nonetheless, common variants in the FTO gene did not show an obvious association with obesity-related phenotypes in Spanish Roma populations [42].

In the analysis of the combined effect of the selected variants, GRS1 and GRS2 yielded similar results; both of them displayed significant positive correlation with obesity. The inclusion of only a subset of SNPs that were found to have significant effects in this study has allowed for creating a genetic risk score profile (GRS2) with increased predictive validity, as reflected by the association measures. The analysis of GRSs stratified by ethnic groups demonstrated differences between the two study populations. Whereas both GRSs revealed a stronger relationship with obesity risk in the HR population, these associations were weakened in the $\mathrm{HG}$ sample, indicating difference in the penetrance of obesity-related variants in our study populations. This finding is an interesting observation because significant interactions of individual SNPs or GRSs with ethnicity could not be established if the two populations were analyzed jointly.

Despite the lack of marked heterogeneity of genetic risk to develop obesity in the study populations, excess body weight, surprisingly, was less frequently observed among Roma than in the HG population, which is consistent with a previous report [43]. This observation may be explained in part by the Roma's generally deprived socioeconomic status [44], which imposes limits the transition from their traditional lifestyle to a westernized one. Although their nutritional characteristics (consumption of fruits and vegetables and type of fat used for cooking) were reported to be generally unhealthier than that of HG population [43], their overall energy intake does not appear to reach the degree with which the HG population can be characterized. Regardless of dietary intake, it is important to consider that other ethnicspecific lifestyle components (alcohol consumption, physical activity levels, or smoking habits) could also act as modifiers of the effect of a given genetic variant on body weight [18]. Our findings suggest that the high environmental variability associated with more favorable socioeconomic conditions and the cultural habits resulting in abundant energy intake of the Hungarian general population highlight the importance of environmental and lifestyle factors 
in the attenuation of penetrance and expression of obesity-predisposing genetic variants. These facts may be possible explanations for the phenotypic differences observed between the two populations.

Several limitations of the present investigation need to be considered. An important point for discussion is that the HR study population is not fully representative of the overall Roma population in Hungary. Due to the sampling design, those Roma who have assimilated within the Hungarian general population or declared themselves as Hungarians were not included in the HR population survey. Moreover, it is also necessary to note that the representative sample of the Hungarian general population included some people who are Roma because the data collection of HG sample did not involve the ascertainment of ethnicity. Similarly, the presence of participants with mixed Roma/non-Roma ancestry could not be excluded in the recruitment of both study populations. Their inclusion may result in a slight underestimation of the differences between the populations. Furthermore, the lack of information both on environmental factors, including physical activity and dietary habits, and gene-environment interactions is a limitation of our work. Lastly, we acknowledge that the impact of SNPs selected from meta-analyses has not been confirmed by GWAS and the possible absence of their association signals may decrease the predictive value of GRS computed in our study. On the other hand, a series of GWAS-established loci were not included in our analysis but could also contribute to the phenotypic differences between the two populations.

In conclusion, this study is the first to investigate the joint effect of obesity-related gene variants among Roma living in segregated colonies and to compare them with data of the majority of the population. Our findings suggest that the differences in obesity prevalence between the HG and HR populations could be primarily explained by ethnicity-related environmental and behavioral factors, and not by genetics. Nevertheless, particular gene-environment interactions might contribute to the distinct penetrance of the obesity-associated genetic factors in populations of different ethnic backgrounds.

\section{Acknowledgement}

This research was supported by the TÁMOP 4.2.2.A-11/1/KONV-2012-0031 'Social Renewal Operational Program - IGEN-HUNGARIAN' and the GINOP-2.3.2-15-2016-00005 project. The projects were co-financed by the European Union and the European Regional Development Fund.

\section{Ethics Approval}

All procedures performed in studies involving human participants were in accordance with the ethical standards of the Ethical Committee of the University of Debrecen (reference No. 2462-2006), the Ethical Committee of the Hungarian Scientific Council on Health (reference No. 8907-0/2011-EKU, 285/PI/11) and with the 1964 Helsinki declaration and its later amendments or comparable ethical standards.

This article does not contain any studies with animals performed by any of the authors.

Informed consent was obtained from all individual participants included in the study.

\section{Disclosure Statement}

The authors declare that they have no conflict of interest. 


\section{References}

1 Martos E, Kovacs VA, Bakacs M, Kaposvari C, Lugasi A: Hungarian diet and nutritional status survey - the OTAP2009 study. I. Nutritional status of the Hungarian population (in Hungarian). Orvosi Hetilap 2012;153: 1023-1030.

2 OECD Health Data 2012; Eurostat Statistics Database: WHO Global Infobase. http://dx.doi. org/10.1787/9789264183896-en (last accessed September 26, 2107).

3 Cahn C, Guild E: Recent Migration of Roma in Europe, 2nd ed. Council of Europe, 2010. www.osce.org/ hcnm/78034?download=true (last accessed September 26, 2107).

4 Moorjani P, Patterson N, Loh PR, Lipson M, Kisfali P, et al: Reconstructing Roma history from genome-wide data. PloS one 2013;8:e58633.

5 Martinez-Cruz B, Mendizabal I, Harmant C, de Pablo R, Ioana M, et al: Origins, admixture and founder lineages in European Roma. Eur J Hum Genet 2016;24:937-943.

6 Sumegi K, Jaromi L, Magyari L, Kovesdi E, Duga B, et al: Functional variants of lipid level modifier mlxipl, gckr, galnt2, cilp2, angptl3 and trib1 genes in healthy Roma and Hungarian populations. Pathol Oncol Res 2015;21: 743-749.

7 Janicsek I, Sipeky C, Bene J, Duga B, Melegh B, et al: Significant interethnic differencies in functional variants of pon1 and p2ry12 genes in Roma and Hungarian population samples. Mol Biol Repts 2015;42:227-232.

8 Szalai R, Magyari L, Matyas P, Duga B, Banfai Z, et al: Genetic polymorphisms in promoter and intronic regions of cyp1a2 gene in Roma and Hungarian population samples. Environ Toxicol Pharmacol 2014;38:814-820.

9 Magyari L, Varszegi D, Sarlos P, Jaromi L, Melegh BI, et al: Marked differences of haplotype tagging SNP distribution, linkage, and haplotype profile of IL23 receptor gene in Roma and Hungarian population samples. Cytokine 2014;65:148-152.

10 Cook B, Wayne GF, Valentine A, Lessios A, Yeh E: Revisiting the evidence on health and health care disparities among the Roma: a systematic review 2003-2012. Int J Public Health 2013;58:885-911.

11 Parekh N, Rose T: Health inequalities of the Roma in Europe: a literature review. Central Eur J Public Health 2011;19:139-142.

12 Carrasco-Garrido P, Lopez de Andres A, Hernandez Barrera V, Jimenez-Trujillo I, Jimenez-Garcia R: Health status of Roma women in Spain. Eur J Public Health 2011;21:793-798.

13 Dobranici M, Buzea A, Popescu R: The cardiovascular risk factors of the Roma (Gypsies) people in centraleastern Europe: a review of the published literature. J Med Life 2012;5:382-389.

14 Kosa Z, Moravcsik-Kornyicki A, Dioszegi J, Roberts B, Szabo Z, et al: Prevalence of metabolic syndrome among Roma: a comparative health examination survey in Hungary. Eur J Public Health 2015;25:299-304.

15 Gallagher A, Cvorovic J, Strkalj G: Body mass index in Serbian Roma. Homo 2009;60:567-578.

16 Poveda A, Ibanez ME, Rebato E: Obesity and body size perceptions in a Spanish Roma population. Ann Hum Biol 2014;41:428-435.

17 Fedacko J, Pella D, Jarcuska P, Siegfried L, Janicko M, et al: Prevalence of cardiovascular risk factors in relation to metabolic syndrome in the Roma population compared with the non-Roma population in the eastern part of Slovakia. Central Eur J Public Health 2014;22(suppl):S69-74.

18 Bell CG, Walley AJ, Froguel P: The genetics of human obesity. Nat Rev Genet 2005;6:221-234.

19 Pigeyre M, Yazdi FT, Kaur Y, Meyre D: Recent progress in genetics, epigenetics and metagenomics unveils the pathophysiology of human obesity. Clin Sci (Lond) 2016;130:943-986.

20 Fu J, Festen EA, Wijmenga C: Multi-ethnic studies in complex traits. Hum Mol Genet 2011;20:R206-213.

21 Li A, Meyre D: Challenges in reproducibility of genetic association studies: lessons learned from the obesity field. Int J Obes (Lond) 2013;37:559-567.

22 Szigethy E, Szeles G, Horvath A, Hidvegi T, Jermendy G, et al: Epidemiology of the metabolic syndrome in Hungary. Public Health 2012;126:143-149.

23 Kosa Z, Széles, G., Kardos, L., Kosa, K., Németh, R., Országh, S., Fésüs, G., McKee, M. Adany, R., Vokó, Z.: Health of the inhabitants of Roma settlements in Hungary, a comparative health survey. Am J Public Health 2007;97: 853-859.

24 Adany R, Kosa K, Sandor J, Papp M, Furjes G: General practitioners' cluster: a model to reorient primary health care to public health services. Eur J Public Health 2013;23:529-530.

25 Gabriel S, Ziaugra L, Tabbaa D: Snp genotyping using the sequenom massarray IPLEX platform. Curr Protoc Hum Genet 2009; Chapter 2:Unit 2.12.

26 Paracchini V, Pedotti P, Taioli E: Genetics of leptin and obesity: a huge review. Am J Epidemiol 2005;162:101114.

27 Speliotes EK, Willer CJ, Berndt SI, Monda KL, Thorleifsson G, et al: Association analyses of 249,796 individuals reveal 18 new loci associated with body mass index. Nat Genet 2010;42:937-948.

28 Willer CJ, Speliotes EK, Loos RJ, Li S, Lindgren CM, et al: Six new loci associated with body mass index highlight a neuronal influence on body weight regulation. Nat Genet 2009;41:25-34.

29 Galbete C, Toledo E, Martinez-Gonzalez MA, Martinez JA, Guillen-Grima F, et al: Pro12ala variant of the pparg2 gene increases body mass index: an updated meta-analysis encompassing 49,092 subjects. Obesity (Silver Spring) 2013;21:1486-1495.

30 Wu J, Liu Z, Meng K, Zhang L: Association of adiponectin gene (ADIPOQ) rs2241766 polymorphism with obesity in adults: A meta-analysis. PloS One 2014;9:e95270. 
31 Lu JF, Zhou Y, Huang GH, Jiang HX, Hu BL, et al: Association of ADIPOQ polymorphisms with obesity risk: a meta-analysis. Hum Immunol 2014;75:1062-1068.

32 Yeung EH, Zhang C, Chen J, Bowers K, Hu FB, et al: Polymorphisms in the neuropeptide y gene and the risk of obesity: findings from two prospective cohorts. The Journal of clinical endocrinology and metabolism 2011; 96:E2055-2062.

33 Thorleifsson G, Walters GB, Gudbjartsson DF, Steinthorsdottir V, Sulem P, et al: Genome-wide association yields new sequence variants at seven loci that associate with measures of obesity. Nat Genet 2009;41:18-24.

34 Brondani LA, Assmann TS, de Souza BM, Boucas AP, Canani LH, et al: Meta-analysis reveals the association of common variants in the uncoupling protein (UCP) 1-3 genes with body mass index variability. PloS One 2014; 9:e96411.

35 Vimaleswaran KS, Li S, Zhao JH, Luan J, Bingham SA, et al: Physical activity attenuates the body mass indexincreasing influence of genetic variation in the FTO gene. Am J Clin Nutr 2009;90:425-428.

36 Cronin RM, Field JR, Bradford Y, Shaffer CM, Carroll RJ, et al: Phenome-wide association studies demonstrating pleiotropy of genetic variants within FTO with and without adjustment for body mass index. Front Genet 2014;5:250.

37 Purcell S, Neale B, Todd-Brown K, Thomas L, Ferreira MA, et al: Plink: A tool set for whole-genome association and population-based linkage analyses. Am J Hum Genet 2007;81:559-575.

38 Skol AD, Scott LJ, Abecasis GR, Boehnke M: Joint analysis is more efficient than replication-based analysis for two-stage genome-wide association studies. Nat Genet2006;38:209-213.

39 Chakraborty R, Deka R: Isolated populations; in Armitage P, Colton T (eds): Encyclopedia of Biostatistics, 2nd ed. New York, Wiley \& Sons, 2005. DOI: 10.1002/0470011815.b2a05056.

40 Tung YC, Yeo GS, O’Rahilly S, Coll AP: Obesity and FTO: changing focus at a complex locus. Cell Metab 2014;20: 710-718.

41 Macekova S, Bernasovsky I, Gabrikova D, Bozikova A, Bernasovska J, et al: Association of the FT0 rs9939609 polymorphism with obesity in Roma/Gypsy population. Am J Phys Anthropol 2012;147:30-34.

42 Poveda A, Ibanez ME, Rebato E: Common variants in BDNF, FAIM2, FTO, MC4R, NEGR1, and SH2B1 show association with obesity-related variables in Spanish Roma population. Am J Hum Biol 2014;26:660-669.

43 Kosa Z, Szeles G, Kardos L, Kosa K, Nemeth R, et al: A comparative health survey of the inhabitants of Roma settlements in Hungary. Am J Public Health 2007;97:853-859.

44 Hajioff S, McKee M: The health of the Roma people: a review of the published literature. J Epidemiol Commun Health 2000;54:864-869. 